\title{
GEOLOGY OF THE JABAL RIAH AREA, \\ KINGDOM OF SAUDI ARABIA
}

by

John D. Wells

U.S. Geological Survey

Open-File Report 82,1049

This report is preliminary and has not been reviewed for conformity with U.S. Geological Survey editorial standards.

Report prepared for

Ministry of Petroleum and Mineral Resources

Deputy Ministry for Mineral Resources

Jiddah, Kingdom of Saudi Arabia

$1402 \mathrm{AH} \quad 1982 \mathrm{AD}$ 
ABSTRACT ................................

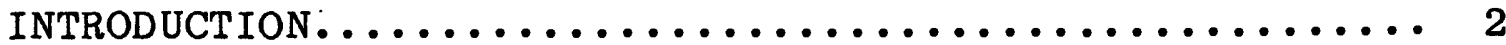

GEOLOGY........................................ 4

Metamorphic rocks....................... 5

Interlayered hornblende and biotite schist.... 5

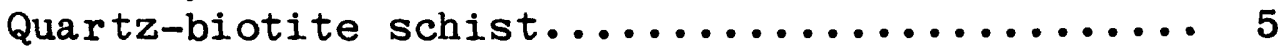

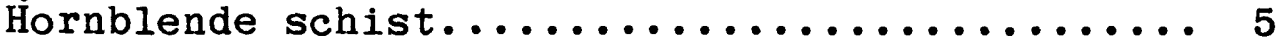

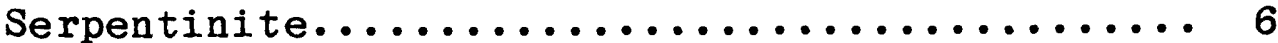

Chlorite schist...................... 6

Intrusive rocks.......................... 7

Diorite-gabbro........................ 7

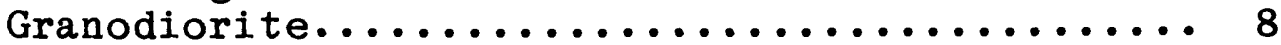

Monzogranite-granodiorite............... 8

Leucocratic quartz porphyry.............. 8

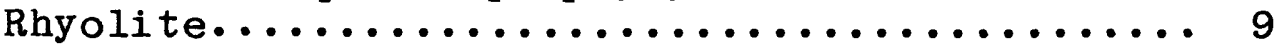

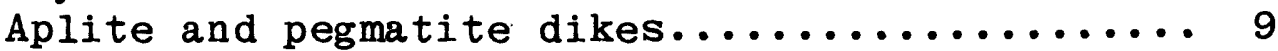

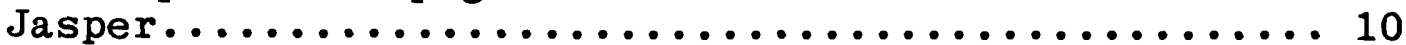

Unconsolidated sedimentary deposits............. 10

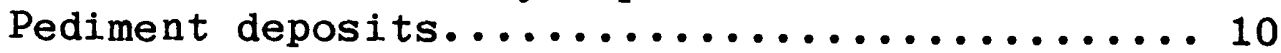

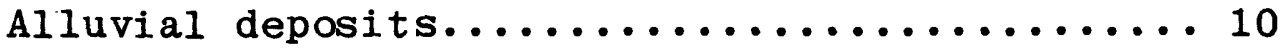

STRUCTURAL GEOLOGY......................... 10

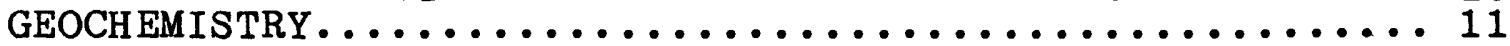

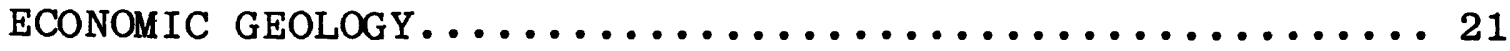

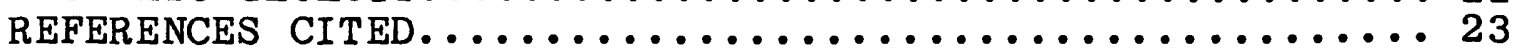

ILLUSTRATIONS

[Plates are in back pocket]

Plate 1. Geologic map of the Jabal Riah area and the Jabal Mahanid group of ancient gold mines

2. Geochemical sample location map of the Jabal Riah area and the Jabal Mahanid group of ancient gold mines

Figure 1. Index map showing location of Jabal Riah area, Jibal al Hamdah quadrangle..........

TABLES

Table 1. Gold and silver contents and descriptions of samples collected in the Jabal Riah area.... 12

2. Maximum, median, and minimum gold and silver contents of various material types collected in the Jabal Riah area......... 19 


\section{GEOLOGY OF THE JABAL RIAH AREA, KI NGDOM OF SAUDI ARABIA}

by

John D. Wells $1 /$

\section{ABSTRACT}

The Jabal Riah area is in the southern part of the Jibal al Hamdah quadrangle (lat $19^{\circ} 00^{\prime} 00^{\prime \prime}$ to $19^{\circ} 07^{\prime} 30^{\prime \prime} \mathrm{N}$, long $43^{\circ} 37^{\prime} 30^{\prime \prime}$ to $43^{\circ} 45^{\prime} 00^{\prime \prime}$ E.) in the southeastern Precambrian Shield, Asir Province, Kingdom of Saudi Arabia. The Jabal Mahanid group of ancient gold mines, which is part of the Jabal Ishmas-Wadi Tathlith gold belt, is in the westcentral part of the area.

Rocks in the Jabal Riah area consist of Precambrian layered metasedimentary and metavolcanic rocks intruded by Precambrian igneous rocks. The metamorphic rocks are, from oldest to youngest, interlayered hornblende and biotite schist, quartz-biotite schist, hornblende schist, serpentinite, and chlorite schist. The igneous rocks are, from oldest to youngest, diorite-gabbro including dikes, granodiorite, monzogranite-granodiorite, leucocratic quartz porphyry, rhyolite, and aplite and pegmatite dikes. A large area of jasper replaces serpentinite. On the valley floors, recent alluvium and pediment deposits overlie the bedrock.

The structure of the area is dominated by a dome centered over the eastern border of the area; leucocratic quartz porphyry forms the core of the dome. Minor folds and faults are present.

The Jabal Mahanid group of ancient gold mines is on a northwest-trending vein system, and major ancient mine areas are found where the system splits or changes direction. The veins consist of zones of brecciated and crushed rock, which are generally less than $0.5 \mathrm{~m}$ wide but may be as wide as $1 \mathrm{~m}$. These zones contain quartz and calcite stringers and commonly are along hornblende schist-serpentinite contacts; however, they also cut both units. Most aplite, pegmatite, and quartz dikes in the area are thin and discontinuous and are intruded along the vein trend. Similar veins, at the same stratigraphic interval, have been found beyond the northeastern part of the map area. The veins contain detectable gold and silver (median gold, approximately $0.14 \mathrm{ppm}$; median silver, approximately $1 \mathrm{ppm}$ ). Gold and silver are most abundant in

1/ U.S. Geological Survey, Denver, Colorado 
calcium-rich rocks and veins; silver was not detected in igneous rocks. Altered wall-rock zones are mineralized as much as $10 \mathrm{~m}$ away from the veins.

Away from the Jabal Mahanid vein-system, silver was detected in the jasper. Gold and silver were detected in minor brecciated and sheared structures and in metasedimentary rocks. Gold was detected in sericitized margins of the leucocratic quartz porphyry, in unaltered rhyolite, and in aplite dikes.

The presence of unusual amounts of gold and silver over a wide area is indicated by the ancient gold mines along veins at or near the hornblende schist-serpentinite contact in the map area and to the south in the Hajrah-Hamdah area and by the widespread evidence of precious metals in igneous rocks and other vein structures. A domed-shaped area, approximately $30 \mathrm{~km}$ in diameter, is outlined by the hornblende schistserpentinite contact and has leucocratic quartz prophyry in the middle. Additional study of this area might reveal economic concentrations of gold and silver.

\section{INTRODUCTION}

The Jabal Riah area is in the southern part of the Jibal al Hamdah 7 1/2-minute quadrangle in the southeastern Precambrian Arabian Shield, Asir Province, Kingdom of Saudi Arabia. The quadrangle is between lat $1^{\circ} 00^{\prime} 00^{\prime \prime}$ and $19^{\circ} 07^{\prime} 30^{\prime \prime} \mathrm{N}$. and long $43^{\circ} 37^{\prime} 30^{\prime \prime}$ and $43^{\circ} 45^{\prime} 00^{\prime \prime} \mathrm{E}$. (fig. 1). The nearest permanent settlement is the village of Tathlith, approximately 50 $\mathrm{km}$ north of the northern boundary of the quadrangle. Access to the area is along unimproved desert tracks. The main road from Tathlith south to Najran extends north-south near the western border of the Jabal Riah area.

The major drainage in this part of the Arabian Shield is Wadi Tathlith, an intermittent stream that flows north and is located west of the quadrangle. Other wadis draining the region are tributaries of Wadi Tathlith. Major water sources within the Jabal Riah area (pls. 1,2) include Wadi al Habanyal along the western boundary, Wadi Atwayah in the southeastern part, Wadi Gaba in the northern part, Wadi Amok in the northwestern part, and Wadis Salup Segel, Salup Cabita, and Marowa in the central part of the area. The lowest altitude in the area is approximately $1,245 \mathrm{~m}$, where Wadi Gaba leaves the northwestern corner of the area, and the highest is $1,519 \mathrm{~m}$, at the top of Jabal Riah ( $\mathrm{pl} .2$ ). The terrain is characterized by isolated masses of granite standing above flat pediment plains, subdued, rounded hills of serpentinite, and steep, rugged hilis of layered metamorphic rocks. 


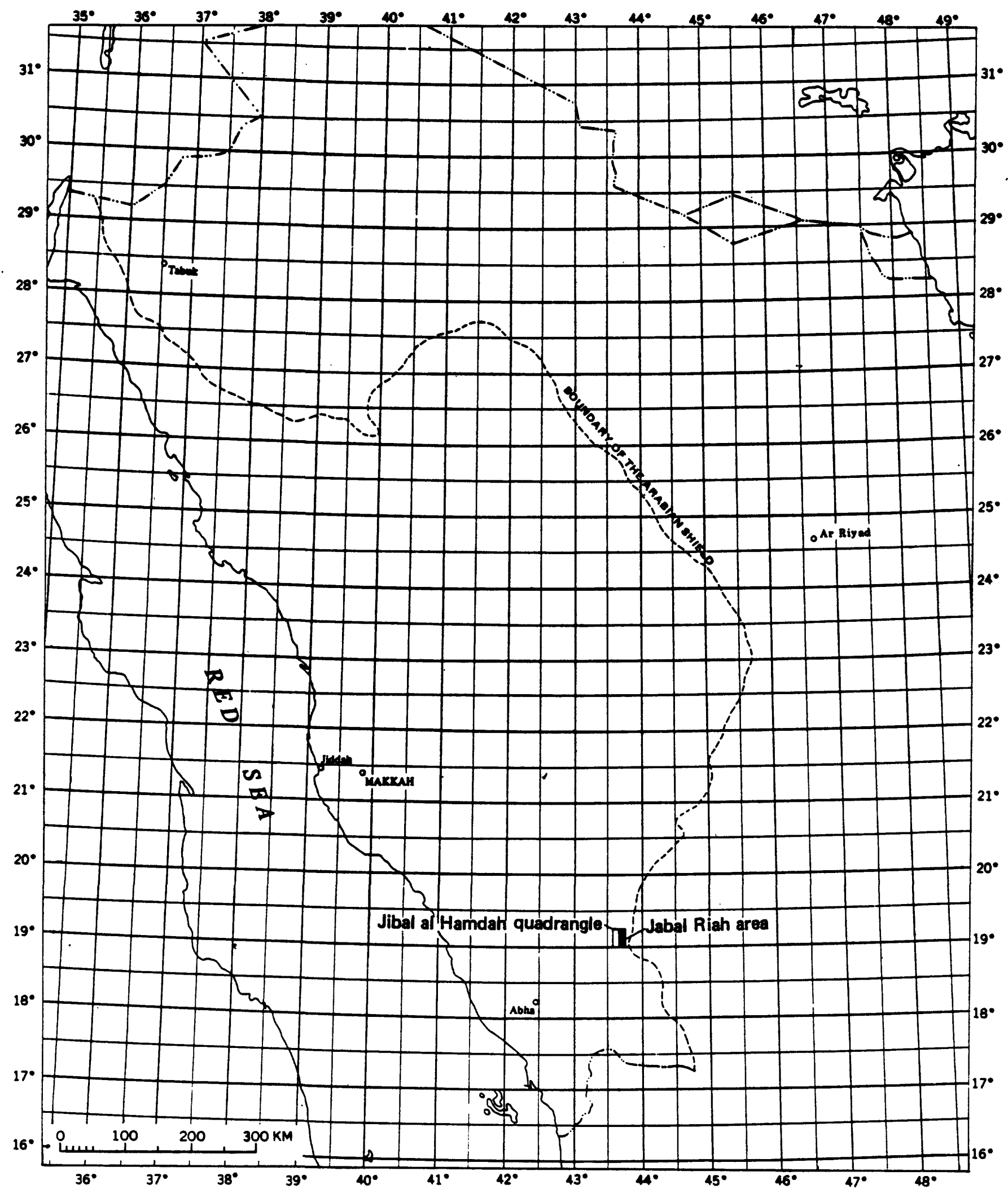

Figure 1.-Index map of western Saudi Arabia showing the location of the Jabal Riah area, in the Jibal al Hamdah quadrangle. 
The eastern half of the Jibal al Hamdah 7 1/2-minute quadrangle, which includes the Jabal Riah area, was mapped as part of an investigation of the Jabal Mahanid group of ancient gold mines, which include Al Halamiya South and North (MODS 00624), Jabal ibn Hassun (MODS 00623), and Riah (MODS 01430) (pls. 1,2). Mineral localities referred to in this report are recorded in the Mineral Occurrence Documentation System (MODS) data bank and identified by a unique 5digit locality number (MODS $x \times x \times x$ ). Data regarding samples of geologic material are recorded in the Rock Analysis Storage System (RASS), and each sample is identified by a unique 6-digit number. Samples cited in this report are in the sample number series 155300-155396. Inquiries regarding either system may be made through the office of the Technical Adviser, Directorate General of Mineral Resources (DGMR), Jiddah, Saudi Arabia.

An evaluation of serpentinites in the Hamdah area, some of which are exposed in the map area, appears in a separate report (Worl and Elsass, 1981). The map area is included in 1:500,000-scale (Brown and Jackson, 1959) and 1:100,000-scale (Overstreet, 1978) geologic maps. Directly to the south of the map area is the Markas quadrangle, which was mapped at a scale of 1:100,000 (Warden, 1982). The Jabal Riah area was mapped and sampled to provide a base for future exploration and to delineate rock types and structures that are spatially related to-gold metalization in the ancient mine area. The area was mapped during February and March 1981 using ground vehicles mostly and 3 days using helicopter transport.

This mapping project is an extension of work done by R. G. Worl in the Jabal al Hajrah 7 1/2-minute quadrangle in an adjacent area to the south (Worl, 1981). An effort was made to use the same map units; therefore, only summary descriptions and special features of map units are given in this report unless the unit was not mapped in the Jabal al Hajrah quadrangle.

This work was performed in accordance with a work agreement between the U.S. Geological Survey (USGS) and the Saudi Arabian Ministry of Petroleum and Mineral Resources.

\section{GEOLOGY}

Precambrian rocks in the Jabal Riah area (pl. 1) consist of layered metasedimentary and metavolcanic units intruded by igneous rocks of several ages.

The oldest layered rocks are in the middle of a major dome-shaped structure and include interlayered hornblende and biotite schist, overlain in succession by quartz-biotite schist, hornblende schist, and serpentinite containing some 
chlorite schist. The oldest igneous rock unit is dioritegabbro followed by granodiorite, monzogranite-granodiorite, leucocratic quartz porphyry, rhyolite, and aplite and pegmatite dikes. Recent alluvial and pediment deposits overlie the bedrock on the valley floors.

\section{Metamorphic rocks}

Interlayered hornblende and biotite schist

The oldest rocks in the area are interlayered hornblende and biotite schist in the east-central part of the map area, where a section approximately $300 \mathrm{~m}$ thick is exposed in the middle of a structural dome (pl. 1). The schist ranges from laminated to thin bedded and medium to fine grained; it consists of quartz, feldspar, biotite, and hornblende. The biotite schist is tan and weathers shaley; it consists mostly of quartz and feldspar and contains from 5 to 25 percent biotite. The variation in biotite content causes the laminations and represents the original compositional layering. Foliation is parallel with the compositional layering in both the biotite and the hornblende schist.

In some areas, hornblende schist layers are dark and range from a few meters to a few tens of meters thick.

Quartz-biotite schist

Quartz-biotite schist overlies the interlayered hornblende and biotite schist unit in the dome in the eastcentral part of the map area (pl. 1); the unit is approximately $1,200 \mathrm{~m}$ thick. The schist is medium to fine grained, tan to light gray, and thin bedded to laminated with a foliation parallel to the compositional layering marked mostly by biotite. The schist is composed of predominantly quartz and feldspar and from 5 to 25 percent biotite.

In the Jabal Riah area this unit contains interbedded and intergradational lenses as much as $10 \mathrm{~m}$ thick of hornblende schist, phyllitic quartzite, and black marble. Locally garnetiferous and pyrite-bearing quartzite layers are present.

\section{Hornblende schist}

Hornblende schist overlies the quartz-biotite schist, and the lower part of the unit outlines the dome-shaped structure in the east-central part of the map area (pl. 1). The upper part of the unit is mixed with the overlying serpentinite in such a way that in places the hornblende schist-serpentinite contact is discordant to the foliation. The contact may be interfingering, and small bodies of serpentinite are included in the hornblende schist. The upper part of the section is deformed by minor folds. The unit is at least $500 \mathrm{~m}$, and possibly as much as $1,000 \mathrm{~m}$, thick. 
The schist is dark gray to black, medium to fine grained, and massive to thin bedded to laminated and contains layers of plagioclase and quartz from 1 to $3 \mathrm{~cm}$ thick. Foliation is parallel with the compositional layering. The unit includes sections as thick as $30 \mathrm{~m}$ where biotite is dominant; layers of quartz-epidote-calcite-garnet intrude the hornblende schist as sills. Many of these sills are sheared and foliated parallel with foliation in the schist and cannot always be distinguished from the massive hornblende schist layers.

Carbonaceous schist was mapped separately by Worl (1981), but in this area the layers are too thin and discontinuous to be mapped as a separate unit. The carbonaceous schist is laminated, black, and soft and weathers light silvery gray.

Serpentinite

Serpentinite is the youngest metamorphic rock in the area (p1. 1); it is intimately mixed with the upper part of the hornblende schist unit and has probably been tectonically injected into the section at its present location. The serpentinite is massive, with no foliation or other internal structure to provide evidence of its movement. It cuts, interfingers with, and parallels layering in the hornblende schist, and small bodies of hornblende schist are included in the serpentinite. The serpentinite has been intruded by numerous, large aplite and pegmatite dikes and some diorite.

The serpentinite crops out as rounded hills, on which the rocks weather reddish-brown and have a rubbly surface resulting from the weathering of angular joint blocks from 2 to $5 \mathrm{~cm}$ in diameter. Both reddish-brown and greenish-gray serpentinite, which have resulted from the alteration of primary olivine and pyroxene, respectively, are present (Worl and Elsass, 1981).

Most of the serpentinite appears amorphous under the hand lens, although chlorite, a fibrous mineral, talc (?), and tremolite-actinolite can be distinguished. Locally large, radiating aggregates of tremolite and actinolite are present. A detailed description of the mineralogy of the serpentinite is included in a report by Worl and Elsass (1981).

Along many contacts with aplite and pegmatite dikes, hydrothermal alteration has produced a carbonate-rich, reddishbrown, friable rock. Locally the serpentinite is silicified.

\section{Chlorite schist}

Chlorite schist in serpentinite crops out in a small area in the northeastern part of the map area (pl. 1). It is dark green to black and in some places contains augen of chlorite 
crystals; in other areas it contains large hornblende crystals. The unit also contains some fine-grained quartzite and hornblende schist. Chloritized zones as wide as $1 \mathrm{~m}$ extend along fractures in the serpentinite for a distance of $1 \mathrm{~km}$ southwest of the chlorite zone.

Thin, altered diorite dikes, which are too small to map, intrude the serpentinite. The heat and fluids associated with the dike intrusion probably altered the serpentinite to chlorite schist.

\section{Intrusive rocks}

Six types of intrusive rocks cut the metamorphic rocks in the Jabal Riah area (pl. 1). They are, in order of decreasing age: diorite-gabbro, including dikes; granodiorite; monzogranite-granodiorite; leucocratic quartz porphyry; rhyolite; and aplite and pegmatite dikes.

\section{Diorite-gabbro}

The diorite-gabbro is part of a larger intrusive unit that extends south into the Jabal al Hajrah quadrangle (Worl, 1981) and is in the northern part of the Jabal Riah area (pl. 1). Large bodies of diorite-gabbro intrude the serpentinite and upper hornblende schist units, and dikes of dioritegabbro intrude all metamorphic rock units but are most commonly found in the hornblende schist and upper part of the quartz-biotite schist; in this area most of the dikes are dioritic.

The diorite-gabbro is massive and medium to fine grained, weathers brown, and has a "salt-and-pepper" appearance caused by light- and dark-colored minerals. The light-colored minerals are quartz and plagioclase, and the dark minerals are hornblende and some biotite.

Dikes consist of diorite and gabbro and their finegrained equivalents; the narrow dikes and the margins of wider dikes are fine grained. In some areas the dioritegabbro unit has intruded the lower part of the hornblende schist unit and the upper part of the quartz-biotite schist unit in such abundance that possibly as much as 25 percent of the mass is diorite. The dikes are too narrow and intricate to map at 1:25,000 scale. Many of the dikes, particularly those in sill form, are foliated parallel to the bedding. Some of the dikes may be relatively young; in the eastern part of the area, a dike cuts leucocratic quartz porphyry, which is one of the youngest rock units in the area. 


\section{Granodiorite}

The granodiorite is in. the northwestern part of the area (p1. 1), where it crops out as rounded hills. It is part of a large pluton that extends northwest and southeast. It intrudes the diorite-gabbro and metamorphic rocks and is in turn intruded by aplite and pegmatite dikes. Small, finegrained diorite bodies less than a few meters in diameter are included in the rock. The granodiorite is well foliated in most places, with the foliation paralleling that of the enclosing metamorphic rocks.

The granodiorite is medium to coarse grained and contains quartz and feldspar crystals and glomeroporphyroblasts aligned with the foliation. The dark minerals consist of clusters of biotite with some hornblende. The granodiorite is gray and weathers reddish brown.

\section{Monzogranite-granodiorite}

The monzogranite-granodiorite unit is a large pluton in the north-central part of the area (p1. 1), where it forms Jabal Riah, and as smaller plutons in the southern part of the area, which continue into the area mapped by Worl (1981). The rock is gray and weathers pink. In the southern part of the mapped area it intrudes diorite-gabbro and hornblende schist, but at Jabal Riah the country rock is mostly serpentinite and some hornblende schist. The monzogranitegranodiorite is generally not foliated, although a weak alignment of minerals is suggested. Intrusion of the unit at Jabal Riah has had little effect on the country rock. The serpentinite is bleached for a distance of from 2 to $4 \mathrm{~m}$ away from the contact, with no visible effect beyond that zone.

The rock is medium to coarse grained and contains pink potassium feldspar phenocrysts as long as $1 \mathrm{~cm}$. In places an aplite phase is near the margin of the unit. The groundmass of the rock consists of quartz, plagioclase, potassium feldspar, and biotite; hornblende is found in the southern part of the unit. Outcrops in the southern part of the unit contain more mafic minerals than those at Jabal Riah.

\section{Leucocratic quartz porphyry}

The leucocratic quartz porphyry crops out as a rounded pluton in the eastern part of the area (p1. 1), where it occupies the core of a major dome-shaped structure. In the central part of the pluton quartz and pegmatite dikes are prominent.

The rock is pink and medium to fine grained and contains conspicuous rounded quartz and inconspicuous euhedral feldspar phenocrysts from 1 to $2 \mathrm{~mm}$ in diameter. A small amount 
of biotite and lesser amounts of secondary muscovite are present. The unit weathers red-brown. A zone of finegrained, sugary-textured rock, containing pink garnets as much as $1 \mathrm{~cm}$ in diameter and clots of muscovite, is affected by sericitic alteration. A sample taken from the border zone contained $3.04 \mathrm{pm}$ gold.

\section{Rhyolite}

Two small plugs of altered quartz porphyry rhyolite intrude hornblende schist in the central part of the area (pl. 1). Most of the rhyolite is stained reddish brown by iron oxide but part is bleached by sericitic alteration and part is silicified by gray quartz containing fine-grained pyrite. Closely spaced veinlets of quartz and biotite, $1 \mathrm{~mm}$ wide, are in much of the rock. Samples of altered rhyolite, one from each of the plugs, contained 0.10 and $0.12 \mathrm{ppm}$ gold.

The original rock was probably a fine-grained, sugarytextured rhyolite containing rounded quartz phenocrysts $1 \mathrm{~mm}$ in diameter and a small amount of biotite. This rock unit may be related to the leucocratic quartz porphyry.

\section{Aplite and pegmatite dikes}

Aplite and pegmatite dikes are very common in the map area and cut all Precambrian rock units. Many more dikes are in the area than could be mapped at $1: 25,000$ scale; they range in width from several centimeters to several tens of meters. They trend in all directions and dip both flatly and steeply. Aplite is more common than pegmatite.

The aplite has a sugary texture, and consists of quartz, feldspar, and biotite; in places the texture coarsens to a granitic texture. The pegmatite typically consists of quartz, feldspar, and biotite; some dikes are composed mostly of quartz, and some dikes contain graphic granite. Many dikes are composed of masses of aplite, pegmatite, and quartz. Most dikes are structureless, but some are foliated parallel to the regional trend.

The genetic relationship of these dikes with one or more of the granitic intrusive units is not known. Some dikes seem to be structurally related to the monzogranitegranodiorite in the Jabal Riah area, and some dikes seem to be spatially related to the leucocratic quartz porphyry. One aplite dike sample contained $2.84 \mathrm{ppm}$ gold; this suggests that some of the dikes were the source of mineralizing fluids. Future work should include detailed mapping and sampling of the dikes to distinguish the types and their economic-mineral content. 
Jasper

An irregularly shaped body of jasper, about $0.25 \mathrm{~km} 2$ in area, caps a hill in the west-central part of the area (pl. 1). The jasper is flat lying and underlain by serpentinite; it appears to have downward dikelike projections that possibly represent feeders. The jasper is light brown, reddish brown, ocherous, and dark red and was formed by replacement of the serpentinite. The contact grades from fresh to altered brown serpentinite containing a few jasper stringers, to a boxwork of stringers, to nearly solid jasper, to wholly jasper. The jasper is banded and veined and is cut by vuggy fractures partly filled with quartz crystals. Two jasper samples contained 1.4 and $1.5 \mathrm{ppm}$ silver.

\section{Unconsolidated sedimentary deposits}

Pediment deposits

Broad, flat areas adjacent to wadis and at an elevation of from 3 to $10 \mathrm{~m}$ above the valley floor are covered with a veneer of boulders and gravel coated with desert varnish. The boulders are as much as $0.6 \mathrm{~m}$ in diameter. Most boulders and gravel are angular.

\section{Alluvial deposits}

The floors of the intermittent streams in the area are covered with alluvial material ranging from silt to gravel in size. The material in the present stream channels is unconsolidated, and the banks of the channels are weakly cemented with caliche. Some black, humic layers are present.

\section{STRUCTURAL GEOLOGY}

The major structural element in the region is the Jabal Ishmas-Wadi Tathlith fault zone (Worl, 1979), a complex series of north-trending faults that extends $350 \mathrm{~km}$. The Jabal Riah area is about $25 \mathrm{~km}$ east of the south-central part of the zone.

The most prominent structural feature in the map area is the dome centered on Jabal La Aval on the eastern boundary of the area. Dips of the bedding away from the middle of the dome range from $20^{\circ}$ to $60^{\circ}$. The dome is not circular but has segments with relatively uniform strikes separated by sharp anticlines. The anticlines plunge away from the central area in northerly, westerly, and southwesterly directions (pl. 1). Along the north-trending anticline, a small thrust fault probably resulted from local compressional forces within the anticline. In the southwestern part of the area, minor anticlines and synclines plunging mostly northeast fold the hornblende schist and serpentinite. 
A dome similar to the one at Jabal. La Aval was mapped by Worl (1981) in the northwestern part of the Jabal al Hajrah quadrangle. In that dome the same types of layered rocks are exposed but not deeply, and, although a core of igneous rocks may be present at depth, it was not mapped.

In the northwestern part of the map area, foliation and bedding generally strike northwest and dip southeast toward the dome, forming a northwest-trending synclinal area occupied by the igneous body and serpentinite at Jabal Riah.

Minor structural features, drag folds, mineral streaking, and mineral rodding are found in the area but are not very common. The attitudes of the fold axes and mineral lineations were determined at 12 locations (pl.1). At eight of the locations the plunge is east-northeast or west-southwest; at the remaining four the plunge is northwest. These attitudes do not correspond to any of the structures related to the doming event but may be related to an earlier deformation.

Only minor faulting was recognized in the area. It is mostly associated with the gold veins, with the exception of one fault in the eastern part of the area. The faults consist of breccia and gouge zones generally less than a meter wide, having displacements that are undetermined but apparently small.

\section{GEOCHEMISTRY}

Geochemical samples were collected from areas of known mineralization, as shown by ancient gold-mine workings, and from other mineralized areas found while mapping. Ninetyseven samples were collected. Sixty-seven samples are from wall rocks and veins marked by ancient workings both along the western side of the mapped area and just outside the northeastern corner of the area. The remaining 30 samples were collected from fracture zones and altered areas. The gold and silver contents are listed in table 1 . The sample locations are shown on plate 2. Table 2 lists maximum, medi.an, and minimum gold and silver contents for various material types.

The gold and silver contents were determined using atomic absorption in the DGMR/USGS geochemical laboratory in Jiddah. The values of 34 other elements were determined using semiquantitative spectrographic analysis; most of these values are low and are not considered to be significant to this study. Any significant values are reported individually.

In 1976, R. G. Worl mapped three mines along the Jabal Mahanid vein system using plane-table methods: Al Hlamiya 


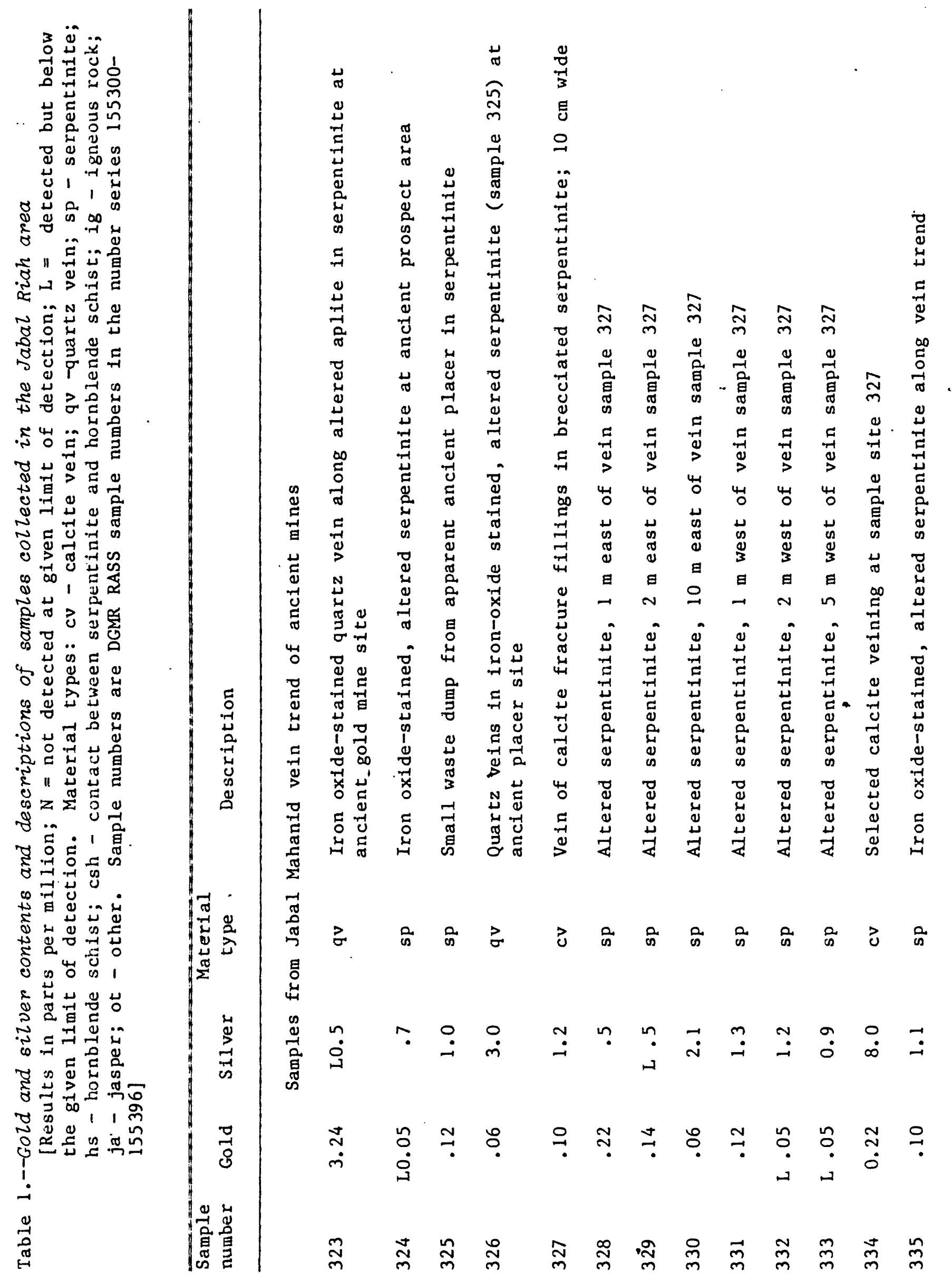




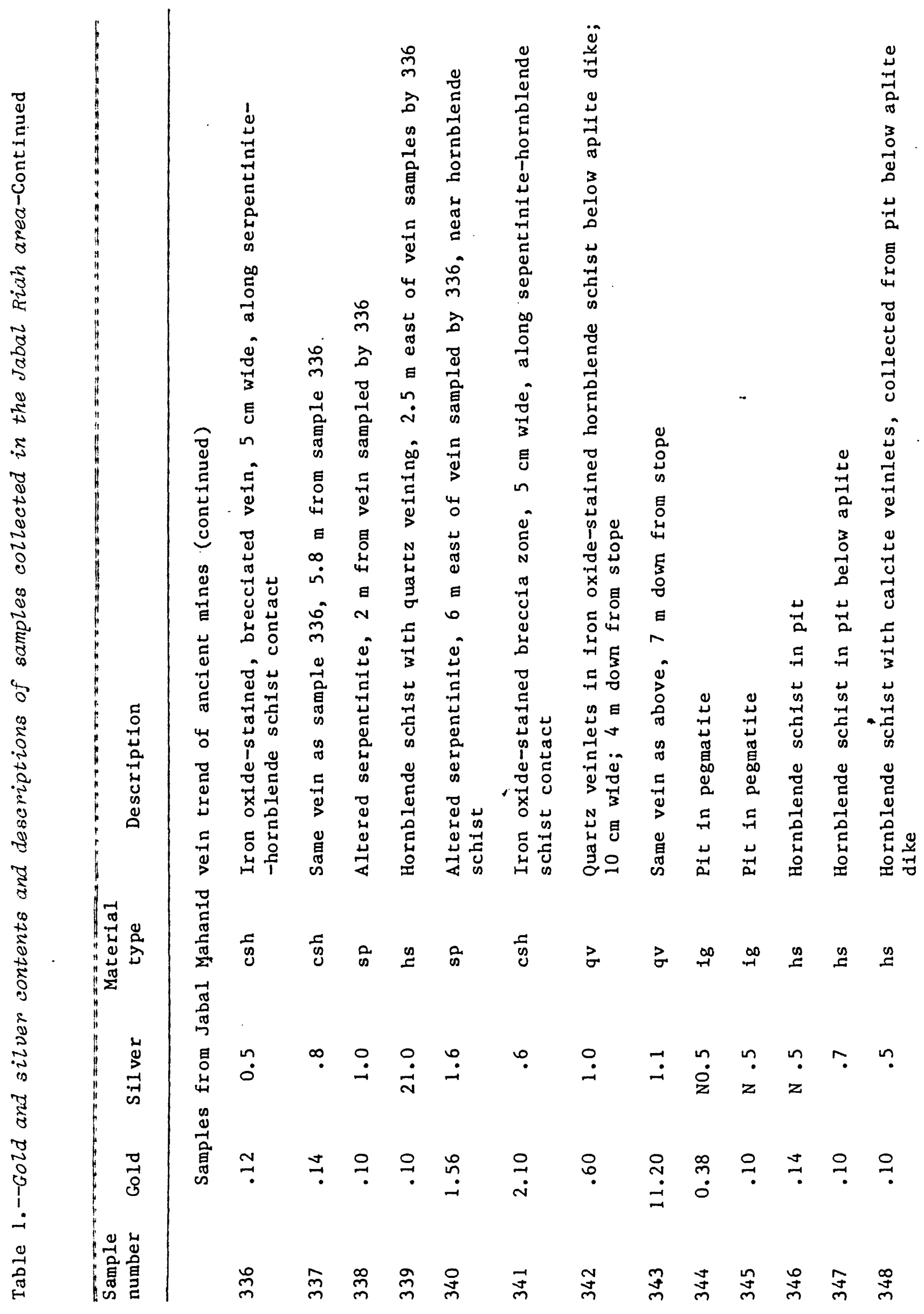




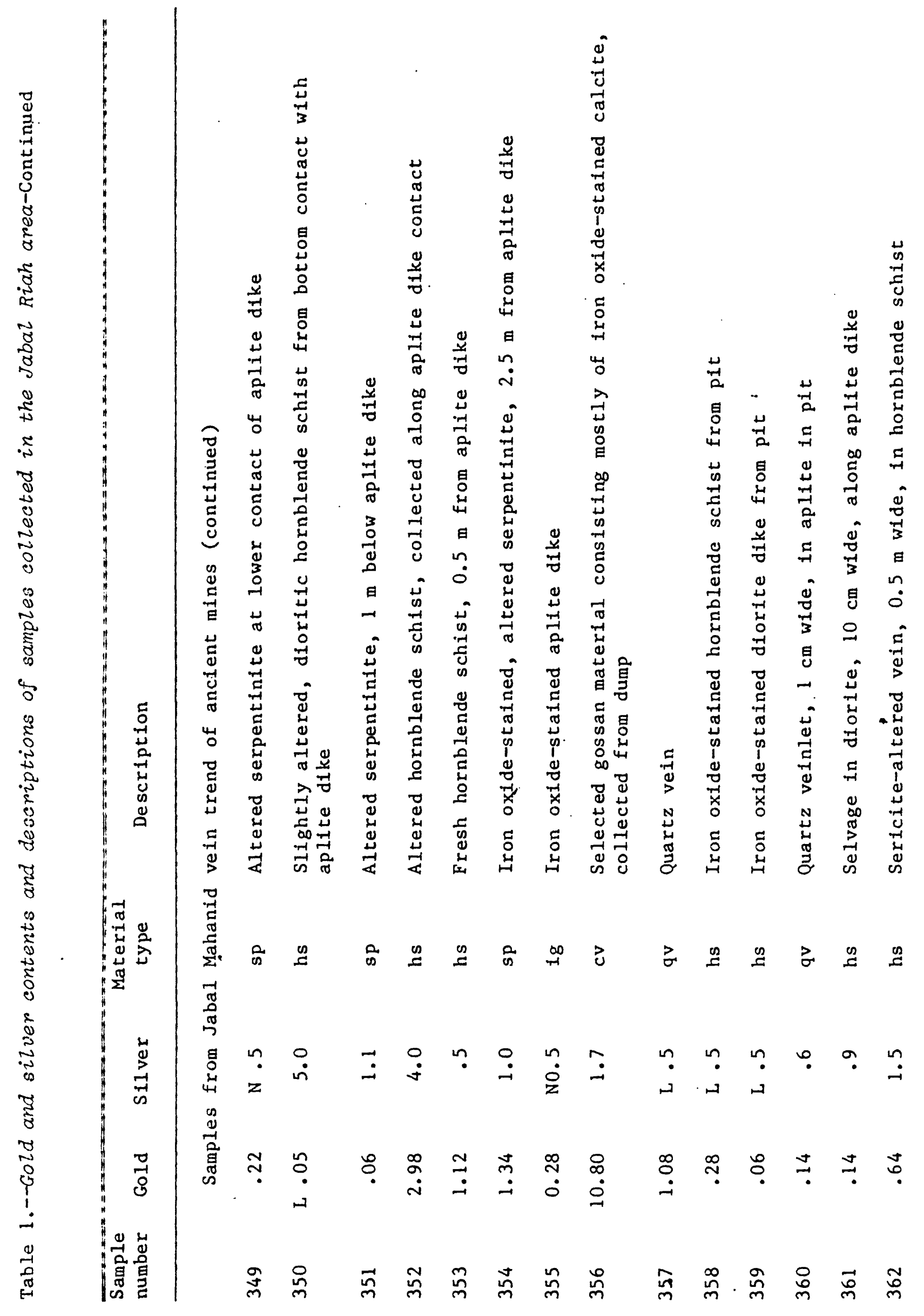




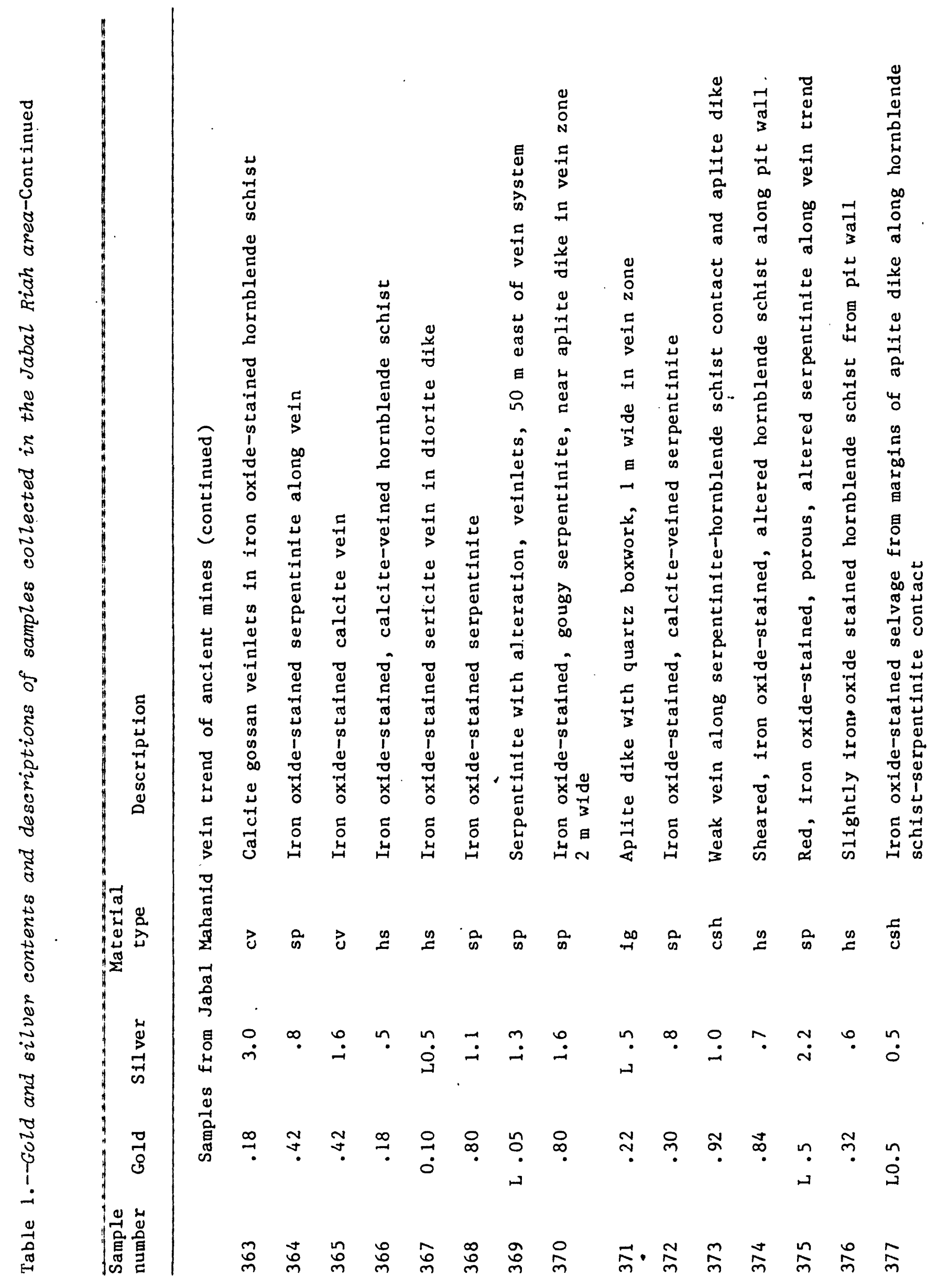




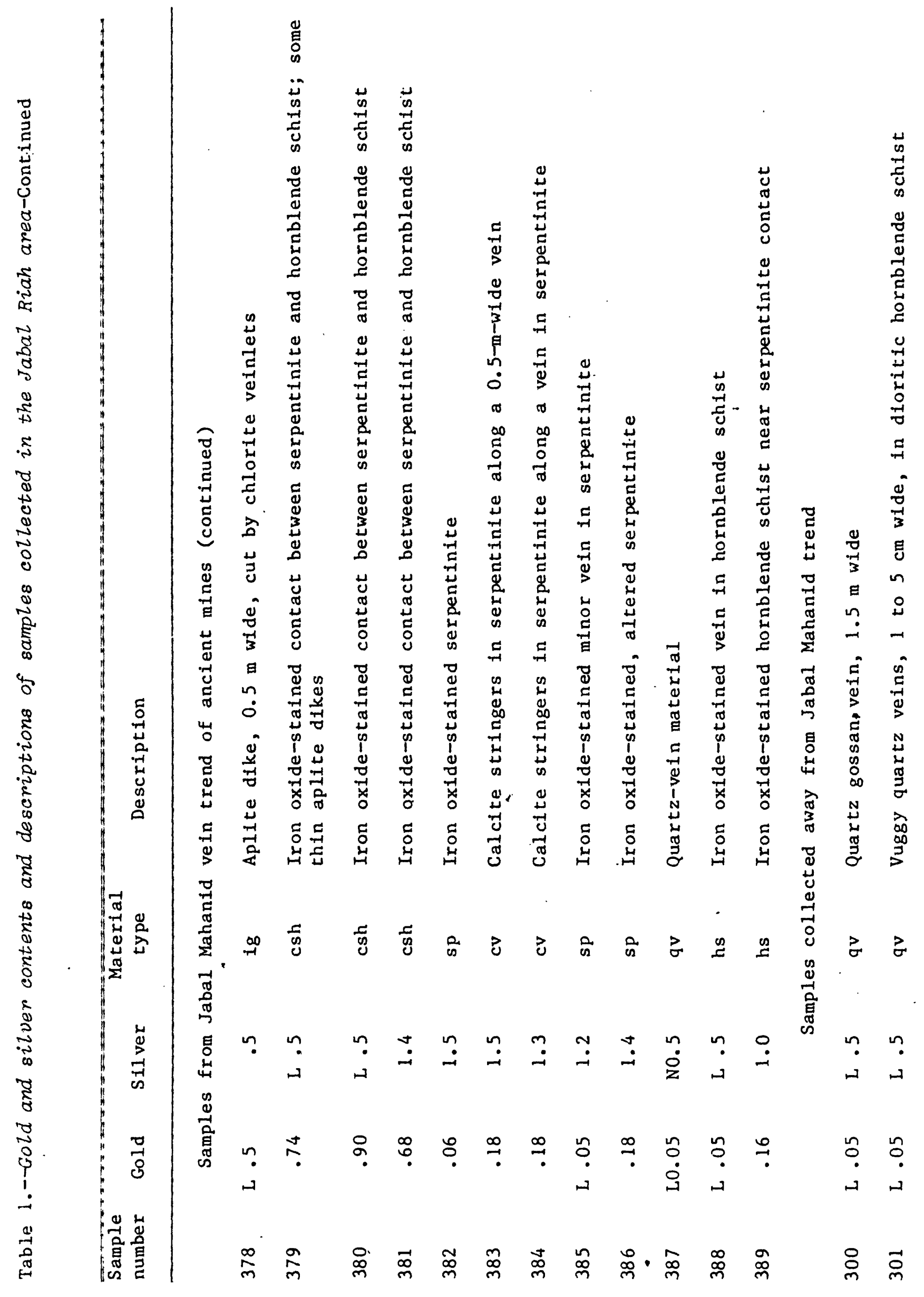




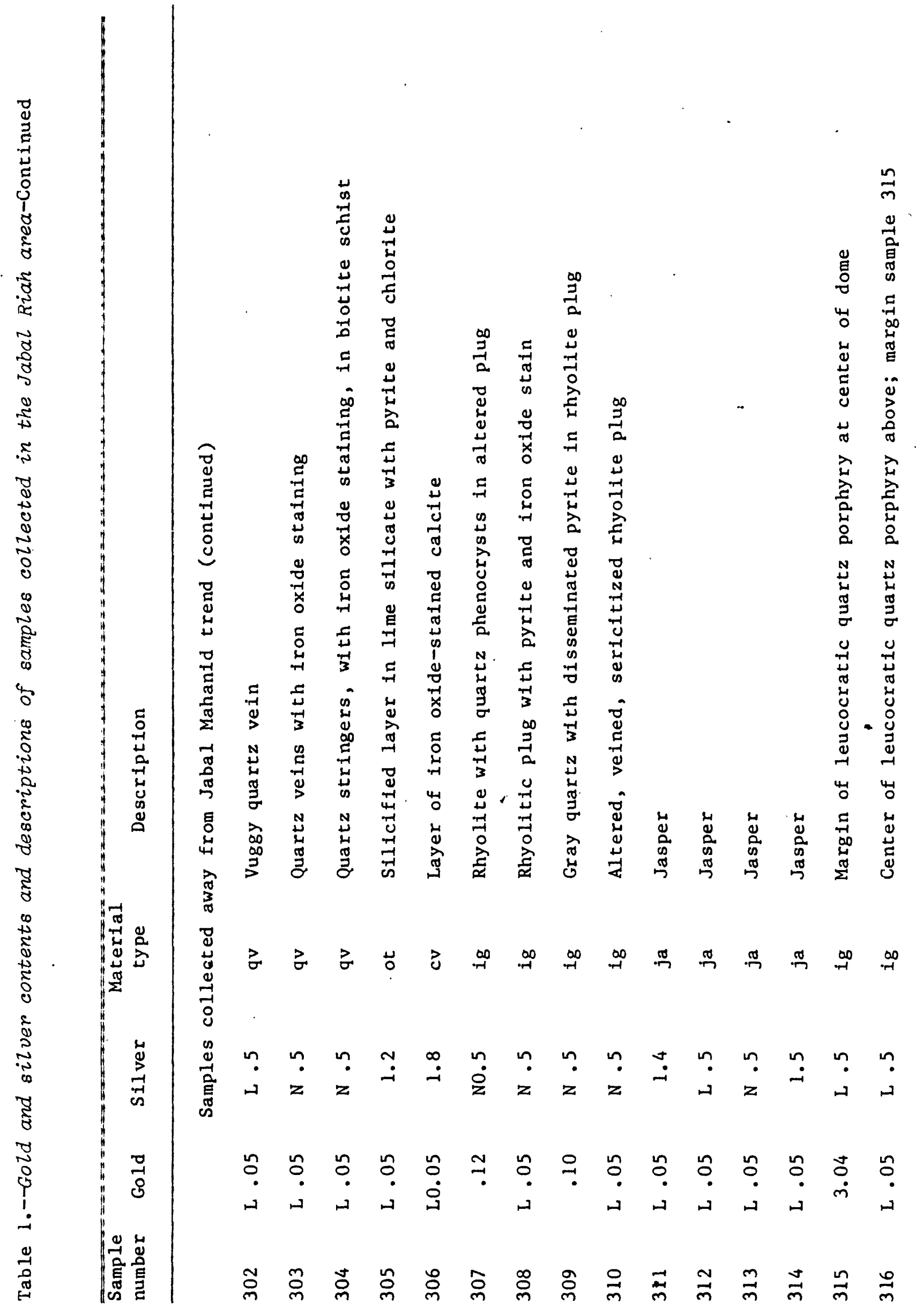




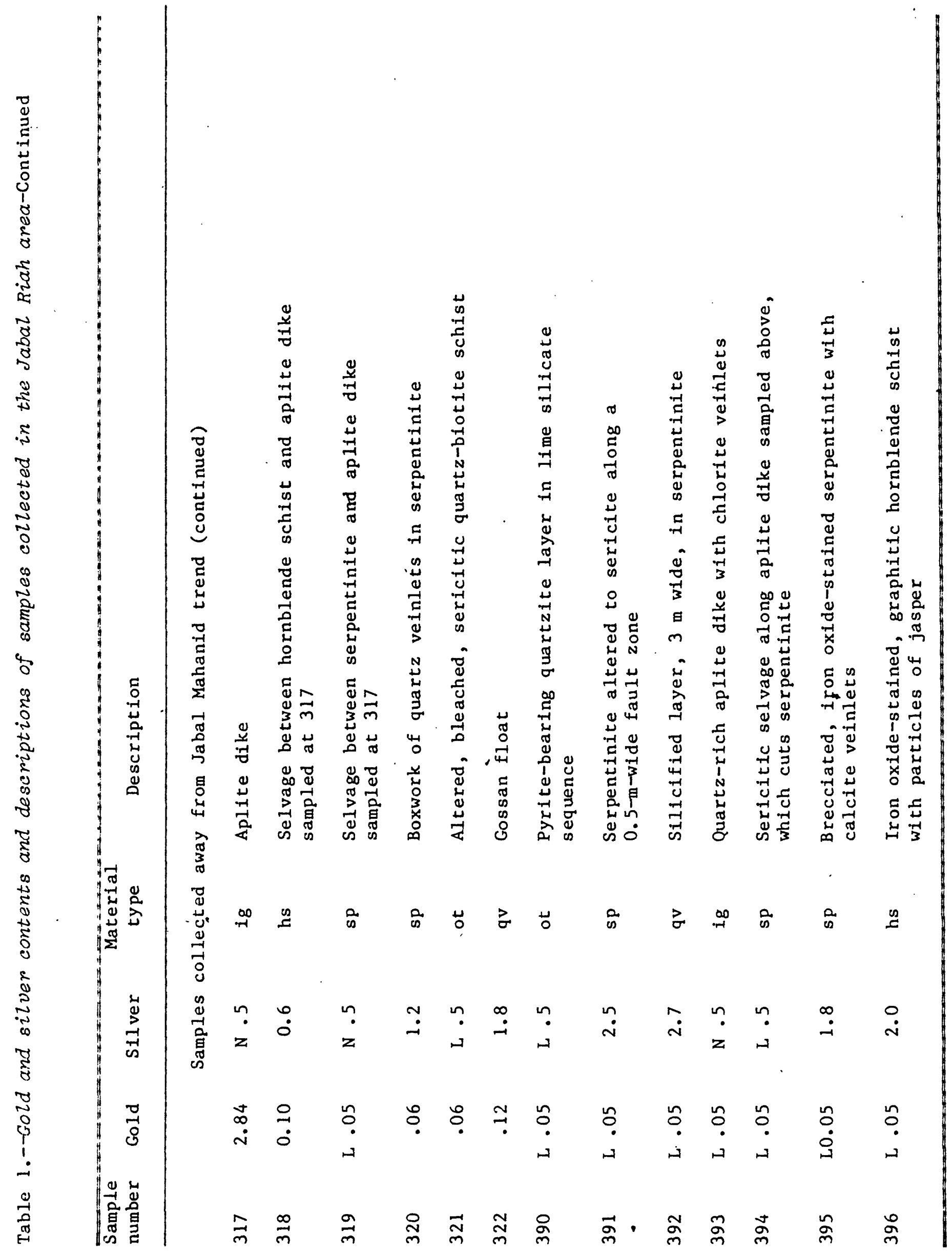


Table 2.--Maximum, mediah, and minimum gold and silver contents of various material types collected in the Jabal Riah area [Results in parts per million and based on data in table 1. $\mathrm{N}=$ not detected at given limit of detection; $\mathrm{L}=$ detected but below the given limit of detection]

$\begin{array}{cccc}\begin{array}{c}\text { Material } \\ \text { type }\end{array} & \text { Minimum Median } & \text { Maximum } & \text { percent of } \\ \text { contents greater } & \text { Number } \\ \text { than limit } & \text { of } \\ \text { of detection } & \text { samples }\end{array}$

Gold

\begin{tabular}{|c|c|c|c|c|c|}
\hline Calcite veins & L0.05 & 0.18 & 10.8 & 99 & \\
\hline Quartz veins & L .05 & .10 & 3.04 & 62 & \\
\hline $\begin{array}{l}\text { Serpentinite } \\
\text { Hornblende }\end{array}$ & L. .05 & .06 & 1.56 & 68 & $\cdot$ \\
\hline $\begin{array}{l}\text { schist } \\
\text { Serpentinite- } \\
\text { hornblende }\end{array}$ & $L .05$ & .14 & 2.98 & 84 & \\
\hline $\begin{array}{l}\text { schist contact } \\
\text { Igneous rocks }\end{array}$ & $\begin{array}{ll}\mathrm{L} & .05 \\
\mathrm{~L} & .05\end{array}$ & $\begin{array}{l}.68 \\
.10\end{array}$ & $\begin{array}{l}2.10 \\
3.04\end{array}$ & $\begin{array}{l}88 \\
62\end{array}$ & \\
\hline
\end{tabular}

Silver

$\begin{array}{lrrrrr}\text { Calcite veins } & 1.2 & 1.7 & 8.0 & 100 & 8 \\ \text { Quartz veins } & \mathrm{N} .5 & \mathrm{~L} .5 & 3.0 & 43 & 14 \\ \text { Serpentinite } & \mathrm{N} .5 & 1.1 & 2.5 & 86 & 28 \\ \begin{array}{l}\text { Hornblende } \\ \quad \text { Schist }\end{array} & \mathrm{N} .5 & .6 & 21.0 & 68 & 19 \\ \begin{array}{l}\text { Serpentinite- } \\ \quad \text { hornblende }\end{array} & & & & & \\ \quad \text { Schist contact } & \mathrm{L} .5 & .8 & 1.4 & 75 & 8 \\ \text { Igneous rocks } & \mathrm{N} .5 & \mathrm{~N} .5 & \text { L0.5 } & 0 & 13\end{array}$


South, Jabal ibn Hassun, and Riah (pl. 2). Dump and vein materials were sampled and analyzed (Worl, 1979, figs. 1012). The gold contents of the samples collected by Worl are similar to those obtained in this study.

The data summarized in tables 1 and 2 indicate that gold is present in all material types and silver is present in all material types except igneous rocks. Also, a greater portion of the samples are mineralized along the vein trend than away from the trend. All calcite veins and all samples having a high calcium content contained silver. Of the 26 samples that contained more than 10 percent calcium, only 8 percent had less than measurable quantities of silver, whereas 58 percent of the 24 samples with 1.0 percent or less calcium contained less than measurable quantities of silver. Samples high in calcium had a median silver content of $1.5 \mathrm{ppm}$ and a maximum silver content of $21.0 \mathrm{ppm}$, but those low in calcium had a median silver content of less than $0.5 \mathrm{ppm}$ and a maximum silver content of $2.7 \mathrm{ppm}$. It is clear that silver and calcium (calcite) are correlative.

The same groups of samples containing high and low calcium contents are compared with their gold contents. In the high-calcium and low-calcium samples, 27 percent and 40 percent, respectively, contained less than determinable quantities of gold, with median gold contents of $0.18 \mathrm{ppm}$ and $0.10 \mathrm{ppm}$ and maximum gold contents of $10.56 \mathrm{ppm}$ and $3.24 \mathrm{ppm}$. Thus, gold is also correlative with calcium (calcite).

Table 2 shows that the gold contents in the hornblende schist and along the contact with serpentinite are somewhat higher than in the serpentinite. The silver contents in these materials show no significant differences, although a sample of hornblende schist with quartz veining contained $21 \mathrm{ppm}$ silver.

A group of four samples (table 1 , samples 323-326) were collected from ancient workings just outside the northeastern corner of the map area. These workings are in approximately the same stratigraphic interval as the main Jabal Mahanid trend, and the gold and silver contents are similar.

Samples from three locations are of particular interest because of their implication as to the distribution and origin of gold mineralization in the region. Sample 315 (table 1) is from the sericitic, aplitic margin of the leucocratic quartz porphyry that occupies the middle of the Jabal La Aval dome, and sample 317 (table 1) is from an aplite dike. These samples contained $3.04 \mathrm{ppm}$ and $2.84 \mathrm{ppm}$ gold, respectively. Samples 307 and 309 , collected from the two altered rhyolite plugs, contained $0.12 \mathrm{ppm}$ and $0.10 \mathrm{ppm}$ gold, respectively (table 1). None of these samples contained measurable amounts of silver. 
These gold and silver contents suggest that aplitic and rhyolitic igneous rocks, which intruded and domed the area at a relatively late geologic time, are the possible source of known mineralization and that major gold deposits may exist.

Samples 311 and 312 , collected from the jasper body, contained 1.4 and $1.5 \mathrm{ppm}$ silver, respectively (table 1). This silver represents the movement and deposition of silica by mineralized solutions. No gold was deposited.

\section{ECONOMIC GEOLOGY}

The Jabal Mahanid group of ancient gold mines is in the west-central part of the map area and is shown on the enlarged inset ( $p l s .1,2$ ). These include Al Hlamiya South, Jabal ibn Hassun, Riah, Al Hlamiya North, and smaller, unnamed workings. The workings from which native gold was-extracted consist of pits, trenches, inclined shafts, and vertical shafts. The pits and trenches are from 1 to $3 \mathrm{~m}$ wide, as long as $100 \mathrm{~m}$, and as deep as $2 \mathrm{~m}$. The shafts range from 2 to $15 \mathrm{~m}$ in depth. Three of these ancient mines, Al Hlamiya South, Jabal ibn Hassun, and Riah, have been mapped in detail by plane-table methods (Worl, 1979).

Mapping done during the present study shows that the ancient workings at Jabal Mahanid are along a single quartzcarbonate vein system in a stratigraphic position at or near the serpentinite-hornblende schist contact (pl. 1). Although the vein system is not continuous, ancient workings beyond the northeastern corner of the mapped area (pl. 1) are in the same stratigraphic interval. Thin aplite, pegmatite, and quartz pegmatite dikes are commonly but not continuously present along the vein system; the dikes are too small to map except at detailed scales. The ancient workings have been described in a regional context by Worl $(1979,1980)$.

In the Jabal Riah area, the Jabal Mahanid vein follows a fault along the serpentinite-hornblende schist contact for most of its length, but parts of the vein cut the serpentinite and hornblende schist. The vein also follows and cuts the small dikes. The most extensive and presumably the most productive ancient workings are along the vein where it branches or changes direction. At the Riah mine the major workings are beneath a thin, flat-lying aplite dike in a small hornblende schist unit.

Most veins consist of a zone of brecciated or crushed rock from a few centimeters to a few meters wide. Rock in this zone is stained by iron oxide, is sericitized, and contains variable amounts of calcite and (or) quartz in irregularly shaped masses or stringers. Where the vein follows the contact of a dike, it is commonly in the form of a micaceous 
selvage. Although sulfides in small amounts were probably once present, none were seen in these weathered exposures.

The intensity and width of wall-rock alteration are variable. Alteration includes sericitization and iron oxide staining. Veinlets and masses of quartz and calcite penetrate the wall rock.

Geochemical sampling indicates that gold is present in all rock and vein types and that silver is present in all but igneous rocks. Base metals are either lacking or present in very small amounts. Although both silver and gold appear to be concentrated in calcite veins and calcium-rich rocks, they are also present in quartz veins. Serpentinite and hornblende schist wall rock are about equally mineralized for distances of as much as $10 \mathrm{~m}$ away from the vein.

The data collected in the present study support the interpretation of Worl (1979) that potentially economic gold deposits in this area are small and of low grade.

Other areas not on the vein trend show minor gold and silver mineralization that offers clues to the origin and distribution of the metals. The silver-bearing jasper body indicates that hydrothermal solutions have penetrated rocks in the area. Also, the presence of gold in the sericitized margin of the leucocratic quartz porphyry, in an aplite dike, and in altered rhyolitic plugs shows the correlation of gold with these igneous rocks, which probably have a common source and are the same age.

The leucocratic quartz porphyry is in the middle of Jabal La Aval dome, which is similar to a dome located $14 \mathrm{~km}$ to the southwest in the northwestern part of the Jabal al Hajrah quadrangle (Worl, 1981). The igneous rocks of the Jabal al Hajrah dome are similar to those at Jabal La Aval and may contain a core of leucocratic quartz porphyry. The HajrahHamdah group of ancient gold mines (Helaby and Worl, 1981) are near the Jabal al Hajrah dome, in a zone at or near the serpentinite-hornblende schist contact. The areas outlined by the serpentinite-hornblende schist contact around both these domes are approximately $30 \mathrm{~km}$ in diameter. The ancient mines, as well as the gold and silver mineralization in vein structures and in metamorphic and igneous rocks scattered through both areas, suggest a broad structural feature, which may contain unusually high amounts of gold and silver.

All varieties of igneous rocks, fresh and altered metamorphic rocks, and fracture systems should be mapped in detail and geochemically sampled in an attempt to determine the origin of the metals and to discover if the metals are deposited in economic and extractable concentrations. 


\section{REFERENCES CITED}

Brown, G. F., and Jackson, R. O., 1959, Geologic map of the Asir quadrangle, Kingdom of Saudi Arabia: U.S. Geological Survey Miscellaneous Geological Investigation Map I-217 A, scale 1:500,000.

Helaby, A. M., and Worl, R. G., 1981, Exploration and evaluation of the Hajrah-Hamdah group of ancient gold mines, Kingdom of Saudi Arabia: U.S. Geological Survey Open-File Report 81-445, IR(SA)-297, 52 p.

Overstreet, W. C., 1978, A geological and geochemical reconnaissance of the Tathlith one-degree quadrangle, sheet 19/43, Kingdom of Saudi Arabia: U.S. Geological Survey Open-File Report 78-1072, IR(SA)-230, 132 p.

Warden, A. J., 1982, Reconnaaissance geology of the Markas quadrangle, sheet $18 / 43 \mathrm{~B}$, Kingdom of Saudi Arabia: Saudi Arabian Deputy Ministry for Mineral Resources Open-File Report USGS-OF-02-41, $58 \mathrm{p}$.

Worl, R. G., 1979, The Jabal Ishmas-Wadi Tathlith gold belt, Kingdom of Saudi Arabia: U.S. Geological Survey Open-File Report 79-1519, IR(SA)-264, $108 \mathrm{p}$.

1980, Gold deposits associated with the Jabal Ishmas-Wadi Tathlith fault zone, in Evolution and mineralization of the Arabian-Nubian Shield: King Abdulaziz University, Institute of Applied Geology Bulletin 3, v. 4: Pergamon Press, New York, p. 61-69.

1981, Reconnaissance geology of the Jabal al Hajrah 7 1/2-minute quadrangle, Kingdom of Saudi Arabia: U.S. Geological Survey Open-File Report 81-1218, IR(SA)-296, 21 p., scale 1:25,000.

Worl, R. G., and Elsass, F. E., 1981, Evaluation of mineralization in serpentinite and enclosing rocks in the Hamdah area, Kingdom of Saudi Arabia: U.S. Geological Survey Open-File Report 81-0446, IR(SA)-276, 33 p. 